\title{
Effect of boiling and roasting on physicochemical and antioxidant properties of dark red kidney bean (Phaseolus vulgaris)
}

\author{
*Roy, M., Imran, M.Z.H., Alam, M. and Rahman, M. \\ Department of Food Engineering and Tea Technology, Shahjalal University of Science and Technology, \\ Sylhet 3114, Bangladesh
}

\begin{abstract}
Article history:
Received: 17 November 2020

Received in revised form: 18 December 2020

Accepted: 22 February 2021

Available Online: 30 June 2021
\end{abstract}

\section{Keywords:}

Phaseolus vulgaris,

Boiling,

Roasting,

Physicochemical properties,

Antioxidant activity

\section{DOI:}

https://doi.org/10.26656/fr.2017.5(3).673

\begin{abstract}
The effects of two processing methods (boiling and roasting) on physicochemical qualities of dark red kidney bean (Phaseolus vulgaris) were investigated. Changes in total polyphenol content (TPC) and antioxidant activity due to processing were also analyzed by using Folin-Ciocaltue method and 1,1 diphenyl-2-picrylhydrazyl (DPPH) assay, respectively. Analysis of physicochemical properties exhibited substantial variations $(\mathrm{p}<0.05)$ in the levels of moisture, ash, protein, fat, carbohydrate, gross energy and $\mathrm{pH}$ of raw and processed beans. Meanwhile, there was no considerable difference $(p<0.05)$ in the fibre content of fresh and processed beans. Investigation of total phenolic content showed the significant $(\mathrm{p}<0.05)$ reduction of phenolic compounds in boiled $(5.53 \pm 0.74 \mathrm{mg} \mathrm{GAE} /$ $\mathrm{g})$ and roasted $(8.15 \pm 1.60 \mathrm{mg} \mathrm{GAE} / \mathrm{g})$ beans than raw samples $(12.55 \pm 1.42 \mathrm{mg} \mathrm{GAE} / \mathrm{g})$. DPPH radical scavenging activity was also decreased significantly $(\mathrm{p}<0.05)$ in boiled and roasted samples with $\mathrm{IC}_{50}$ value of $0.0608 \pm 0.0765 \mathrm{mg} / \mathrm{mL}$ and $0.0523 \pm 0.0026 \mathrm{mg} / \mathrm{mL}$, respectively. In the case of household cooking, keeping boiling water would be advised for the preservation of minerals, vitamins and phenolic compounds. The roasting process may be used to develop high-quality health-promoting dark red kidney bean products.
\end{abstract}

\section{Introduction}

The situation of global food insecurity is worsening day by day. Many developing countries are undergoing a threat of malnutrition. In the rural areas of Bangladesh, many people don't have the idea of having a balanced diet, especially the consumption of enough protein, vitamins and minerals (Sarkar, Arafat, Alam et al., 2020). As prices of animal protein like meat, fish, milk, egg and more are quite high in the range of the people living under the poverty line, plant protein source can be very much effective for keeping good health of rural children and getting rid of malnutrition. The affordable and feasible way of maintaining good health and alleviating malnutrition is to promote and encourage consumers to keep plant-based proteins in their diets. Generally, legumes are a very good source of protein and they grow a lot all over Bangladesh. There are a lot of legumes cultivated in Bangladesh like- lentil, chickpea, black gram, mung bean, groundnut, kidney bean etc. Legume crops as food occupy about $5 \%$ of the cropped area of Bangladesh but play a significant role in rain-fed agriculture (Rahman et al., 2000).

Legumes generally contain a relatively high amount of protein than any other plant food sources. Kidney bean (Phaseolus vulgaris) is one of the neglected tropical legumes that can be used to improve the nutritional wellbeing of rural mass people of Bangladesh, because of its high protein content (Roy, Haque, Das et al., 2020). It also contains micronutrients like iron, zinc and also rich in crude fibre, vitamin A, E and more (Olanipekun et al., 2015). Kidney bean is a type of herbaceous annual plant grown worldwide for its edible dry seed. Its leaf is also occasionally used as a vegetable and the straw as fodder. It is found abundantly in the Sylhet region of Bangladesh. Along with other Phaseolus species, the dark red kidney bean is a member of the legume family Fabaceae. Again, beans are rich in ample amount of phenolic compounds that possess different levels of antioxidative activity. Antioxidants are special kind of molecules that can inhibit the oxidation process of organic molecules (Roy, Sarker, Azad et al., 2020; Sarker, Chakraborty and Roy, 2020). They are very important for food preservation as well as the defence of living systems against oxidative stress (Nisbett and Masuda, 2003). It is suspected that antioxidants play a significant role in preventing the progression of chronic diseases such as cancer, heart disease, stroke, 
Alzheimer's, rheumatoid arthritis and cataracts. (Alam et al., 2020; Sarkar, Ahmed, Alam et al., 2020). These health benefits have been at least partially attributed to the presence of antioxidant components in beans, especially polyphenols (Xu and Chang, 2008). Therefore, the consumption of beans can be very much beneficial in keeping good health. Aside from the high nutritive value, kidney bean inherits some anti-nutritive components like tannin, saponin, phytohaemaglutinin (PHA) etc. Several studies showed that heat treatment like boiling and roasting can lower the composition of anti-nutritive values (Olanipekun et al., 2015). The roasting process is more effective than boiling in terms of lowering the anti-nutritive composition (Olanipekun et al., 2015).

Boiling and roasting are common forms of household preparation of beans. The roasting process develops the aroma of the beans. Seeds are consumed directly in roasted form. Sometimes delicious dishes are made with it like curry. Thus, they are consumed in boiled form. Some dishes are prepared from flour. Therefore, it is very much important to know what happens to their antioxidative and other physicochemical properties during common domestic processes like boiling, roasting etc. The objectives of this study were to determine the physicochemical quality and to investigate the effects of processing on the phenolic content and antioxidant activity of dark red kidney bean.

\section{Materials and methods}

\subsection{Sample collection}

The sample, dark red kidney bean (Phaseolus vulgaris) was purchased from the local market of Sylhet, Bangladesh. Any visible insect or physically damaged beans were separated from the stock.

\subsection{Sample preparation}

The fresh beans were divided into three groups for the preparation of raw, boiled and roasted samples. The first group was ground using a blender mill and then sieved. Thus, the raw flour was extracted for further analyzing processes. The flour was kept in an airtight container at a cool temperature.

\subsubsection{Boiling process}

The second group was boiled along with water at a temperature of $100^{\circ} \mathrm{C}$ for $3 \mathrm{hrs}$ with the help of an electric induction heater. Further, the boiled beans were dried in an oven at $105^{\circ} \mathrm{C}$ for $5 \mathrm{hrs}$. After that, the dried beans were ground using a blender (Panasonic P305) and then sieved. Thus, the flour was extracted for further analyzing processes. The flour was kept in an airtight container at a cool temperature.

\subsubsection{Roasting process}

The third group was roasted at a temperature of $120^{\circ}$ $\mathrm{C}$ for 25 mins with the help of an electric induction heater. The beans were stirred continuously for avoiding any phenomenon or uneven roasting. Then the fried beans were ground using a blender (Panasonic P305) and then sieved. After that, the flour was kept in an airtight container at a cool temperature for further analyzing processes.

\subsection{Physicochemical analysis}

All the experiments were briefly described below which were carried out on a dry basis.

\subsubsection{Determination of moisture content}

The moisture content was measured according to the official method of AACC (2000). At first, $1 \mathrm{~g}$ of the sample was taken and placed in an oven set at $105^{\circ} \mathrm{C}$ for $3 \mathrm{hrs}$. The sample was allowed to cool. Then, the weight of the cooled sample was measured. The temperature was set to $105^{\circ} \mathrm{C}$ to heat the sample once again for half an hour, followed by subsequent cooling in a desiccator and measured the weight. This process of heating was continued till the weight difference between two consecutive reading is more or less $1 \mathrm{mg}$. The lowest weight was recorded. The following formula was used to measure the moisture content of the sample:

Moisture $(\%)=\frac{\text { weight of the fresh sample-weight of the dry sample }}{\text { weight of the fresh sample }} \times 100$

\subsubsection{Determination of total ash}

The AACC (2000) method was used to determine the total ash content. At first two gm of the sample was put in a crucible and it was allowed to burn fatty substance in a Bunsen burner. After that, it was placed in a muffle furnace and the temperature was set to $550^{\circ} \mathrm{C}$ for $3 \mathrm{hrs}$. The temperature was set to $550 \pm 10^{\circ} \mathrm{C}$ to heat the sample once again for half an hour, followed by subsequent cooling in a desiccator and measured the weight. This process of heating was continued till the weight difference between two consecutive reading is more or less $1 \mathrm{mg}$. The lowest weight was recorded. Finally, ash was calculated by the following formula:

$$
\text { Ash (\%) }=\frac{\text { weight of ash }}{\text { weight of sample }} \times 100
$$

\subsubsection{Determination of fat}

The fat content was measured according to Folch (1957). A mass of $1 \mathrm{~g}$ of samples was weighed and placed in a centrifuge tube. Approximately $5 \mathrm{~mL}$ of Chloroform/Methanol (2:1) was added with the samples. 
Then the samples were centrifuged at $2000 \mathrm{rpm}$ for 5 mins. The upper phase of samples was removed and taken in a test tube and centrifuge tubes were then rinsed with Chloroform/Methanol solution. $8 \mathrm{~mL}$ of $0.74 \% \mathrm{KCl}$ solution was added to the sample. The sample was then allowed to sit for two distinct liquid phases to appear. After that, the samples were heated in a water bath at $80^{\circ}$ $\mathrm{C}$ for the removal of the solvent solution and then samples were dried in an oven at $105^{\circ} \mathrm{C}$ for $1 \mathrm{hr}$. Samples were cooled in a desiccator. The weight was recorded. Finally, fat was calculated using the following formula:

$$
\begin{aligned}
& \text { Fat }(\%)=\frac{\text { weight of test tube and fat }- \text { weight of test tube }}{\text { weight of sample }} \times 100 \\
& \text { 2.3.4 Determination of protein }
\end{aligned}
$$

\subsubsection{Determination of protein}

Protein was determined by the modified method of Horwitz et al. (1970). At first $2 \mathrm{~g}$ of each sample were taken in three $250 \mathrm{~mL}$ KJeldahl flask. In each flask, $2 \mathrm{~g}$ of digestion mixture and $25 \mathrm{~mL}$ of concentrated sulphuric acid had been added. The flask was positioned in an intended direction on the stand in the digestion chamber and heated constantly until the frothing had stopped and the flask was simmered rapidly. The solutions became clear in 15 to 20 mins and was then heated for 45 mins. After cooling, $100 \mathrm{~mL}$ water was added to each flask and they were separately transferred quantitatively to $1 \mathrm{~L}$ round bottom flasks; the final volume was about $500 \mathrm{~mL}$. Enough $\mathrm{NaOH}$ solution was added gently down the side to form precipitates at cupric hydroxide and immediately connected to a stream-trap and condenser. In each of three $500 \mathrm{~mL}$ conical receiving flasks, $50 \mathrm{~mL}$ of the boric acid solution, $50 \mathrm{~mL}$ distilled water and 5 drops of indicator solution were added. Positioning the condenser, distillation was carried out for $40-50 \mathrm{~min}$ or until about $250 \mathrm{~mL}$ of distillate was obtained for each sample. The contents of the receiving were titrated against $\mathrm{HCl}$ solution. Protein conversion factor (6.25) was used to calculate the per cent protein from the nitrogen determination. Percentage of nitrogen and protein was calculated by the following equations:

Nitrogen $(\%)=\frac{(\mathrm{Ts}-\mathrm{Tb}) \times \text { Normality of HCl } \times \text { Molecularweight of Nitrogen }}{\text { Weight of sample } \times \text { Weight of sample taken } \times 1000} \times 100$

Protein $(\%)=$ Nitrogen $(\%) \times 6.25$

\subsubsection{Determination of carbohydrate content}

Carbohydrate content was determined (default) using the following formula:

Carbohydrate $\%=100-(\%$ of moisture + ash + fat + protein)

\subsubsection{Determination of gross energy}

Gross energy was calculated based on the formula given by Eknayake et al. (1999).
Gross energy $(\mathrm{kJ}$ per $100 \mathrm{~g}$ dry matter $)=($ crude protein $\times$ $16.7)+$ (crude lipid $\times 16.7)+($ crude carbohydrates $\times$ 16.7)

\subsubsection{Determination of fibre content}

Approximately $2 \mathrm{~g}$ of moisture and fat-free sample was taken into a $500 \mathrm{~mL}$ beaker. Moisture and fat were removed according to the method and procedure described in the moisture and fat determination. $200 \mathrm{~mL}$ of $0.255 \mathrm{~N}$ Sulphuric acid solution was added to the beaker and boiled for 30 mins. Keeping the volume constant by the addition of distilled water at frequent intervals. After filtering and washing the residue to free from acid, the substance was moved to the same beaker and $0.313 \mathrm{~N} \mathrm{NaOH}(200 \mathrm{~mL})$ was added. It was then allowed to boil for 30 mins and the mixture was once again filtered, the residue was washed away to free from alkali. It was then allowed to dry overnight at $105^{\circ} \mathrm{C}$ and weighted. Finally, the crucible was heated in a muffle furnace at $600^{\circ} \mathrm{C}$ for $3-5$ hours, cooled and weighed again. The loss in the weights represents the weight of fiber. The crude fiber was calculated from the following equation:

\section{Crude fiber $=\frac{\text { Loss in weight }}{\text { Weight of moisture and fat free sample taken }} \times 100$ \\ 2.3.8 Determination of $p H$}

The $\mathrm{pH}$ of the samples was determined by the method of AOAC suggested by Horwitz et al. (1970) by using a pH meter (H1 98106, HANNA).

\subsection{Determination of total polyphenol content}

The total phenolic compound was estimated according to the method of Velioglu et al. (1998). Firstly, sample $(1.0 \mathrm{~mL})$, distilled water $(1.5 \mathrm{~mL}), 0.1 \mathrm{M}$ Folin-Ciocaltue reagent $(0.5 \mathrm{~mL})$, and the contents were mixed properly. About $20 \%$ sodium carbonate solution $(1.0 \mathrm{~mL})$ was added to the mixture after $1 \mathrm{~min}$. The mixture was incubated at $37^{\circ} \mathrm{C}$ for half an hour and measured absorbance at $750 \mathrm{~nm}$. The polyphenol content of the sample was determined by using the known concentrations of the gallic acid standard curve and was estimated as gallic acid equivalent (GAE). The standard curve was used for the measurement of total Phenolic content. The standard curve was made by using Gallic acid at different concentration $(0.2 \mathrm{ppm}, 0.4 \mathrm{ppm}, 0.6$ ppm, $0.8 \mathrm{ppm}, 1 \mathrm{ppm})$. Figure 1 represents the standard curve made by Gallic acid.

Calculation of total Polyphenol content: $\mathrm{y}=0.629 \mathrm{x}+$ 0.344

Where $\mathrm{y}=$ absorbance found by the sample tested, $\mathrm{x}=$ concentration found from the standard curve 


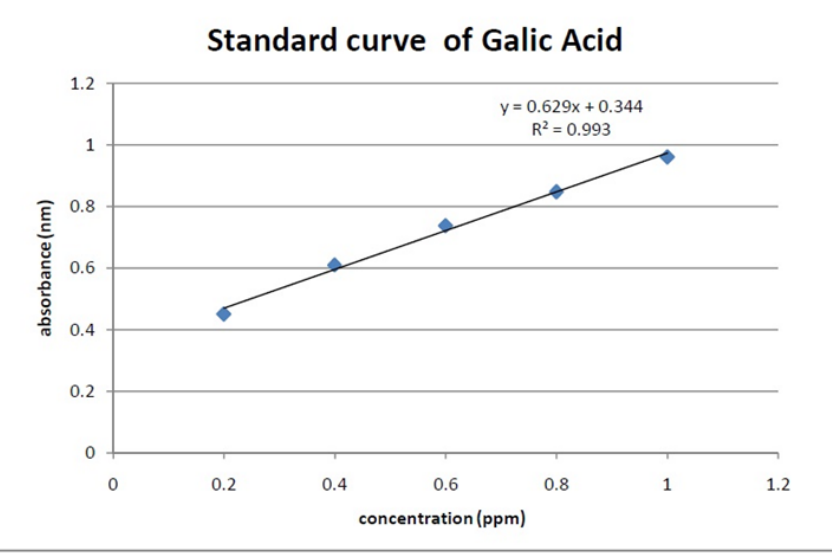

Figure 1. Standard curve of gallic acid for phenolic content

\subsection{Determination of antioxidant activity}

The antioxidant activity was calculated according to the method described by Yen and Chen (1995). Briefly, $2.0 \mathrm{~mL}$ sample and $2.0 \mathrm{~mL}$ of $0.16 \mathrm{mM}$ DPPH solution (methanolic) were mixed together. After vortexing the mixture for $1 \mathrm{~min}$, it was allowed to stand at ambient temperature for half an hour in the dark. The absorbance of the mixture was taken at $517 \mathrm{~nm}$. The scavenging activity of the DPPH radical was estimated using the following formula-

Scavenging effect $(\%)=[1$ - (A sample - A sample blank)/ A control] $\times 100$

\subsection{Statistical analysis}

The experiments were carried out in triplicates and the data obtained from experiments were gathered and analyzed using the Statistical Package for the Social Sciences (SPSS) (Version 21; IBM corporation, 1989). Analysis of Variance was used to determine the significant difference among raw, boiled and roasted flour for physicochemical analysis, determination of TPC and antioxidant activity. The significant difference was determined at $\mathrm{p}<0.05$.

\section{Result and discussion}

3.1 Physicochemical properties of raw, boiled and roasted dark red kidney bean

\subsubsection{Moisture content}

Boiled beans contain $12.13 \pm 0.28 \%$ moisture whereas raw beans contain $6.25 \pm 0.22 \%$ and roasted beans contain
$4.05 \pm 0.15 \%$ moisture. The moisture content of boiled beans increased significantly $(\mathrm{p}<0.05)$ and the moisture content of roasted beans decreased significantly $(p<0.05)$ than the raw beans (Table 1). It is due to the processing techniques used in this study (Olanipekun et al., 2015). Low moisture content in raw and roasted beans indicate their high storage stability than boiled beans. Especially, the lowest moisture content in roasted beans indicates that roasting is a favourable technique to increase the shelf life of dark red kidney bean seeds. Because high moisture content favours microorganisms that are responsible for the spoilage of food. Low moisture content retards the growth of microorganisms which plays a significant role in food preservation. A similar trend was shown by Audu and Aremu (2011) for red kidney bean. Again, similar results were reported by Olanipekun et al. (2015) for white kidney bean where boiled samples had higher moisture than the raw and roasted bean.

\subsubsection{Total ash content}

There were $4.82 \pm 0.27 \%, \quad 3.35 \pm 0.42 \%$ and $4.40 \pm 0.51 \%$ ash contents in raw, boiled and roasted samples, respectively (Table 1 ). The ash content in raw seeds was almost similar to that reported by Audu and Aremu (2011) for red kidney bean. In this study, no significant $(p<0.05)$ changes were observed for ash content in a roasted and raw sample. Meanwhile, in the boiled seeds ash content reduced significantly $(p<0.05)$ than raw and roasted seeds. It may be due to the fact that certain minerals might be diffused into the boiling water which was also previously observed by Wang et al. (2009).

\subsubsection{Fat content}

Fat content $(2.66 \pm 0.18 \%)$ significantly $(\mathrm{p}<0.05)$ decreased in boiled samples than raw and roasted beans. Nutrient, as well as lipid compound, may degrade and leach during the boiling process (Audu and Aremu, 2011). That's why fat content might be reduced significantly $(\mathrm{p}<0.05)$ during boiling. There were no significant differences between raw $(3.63 \pm 0.22 \%)$ and roasted $(3.91 \pm 0.19 \%)$ samples (Table 1 ).

Table 1. Physicochemical composition of raw, boiled and roasted dark red kidney bean

\begin{tabular}{ccccccccc}
\hline Sample type & Moisture (\%) & Ash (\%) & Fat (\%) & Protein (\%) & CHO (\%) & $\begin{array}{c}\text { Gross energy } \\
(\mathrm{kJ} / 100 \mathrm{~g})\end{array}$ & Fibre (\%) & pH \\
\hline Raw & $6.25 \pm 0.22^{\mathrm{b}}$ & $4.82 \pm 0.27^{\mathrm{b}}$ & $3.63 \pm 0.22^{\mathrm{b}}$ & $26.08 \pm 0.14^{\mathrm{b}}$ & $59.22 \pm 0.14^{\mathrm{b}}$ & $1561.43 \pm 8.54^{\mathrm{b}}$ & $5.45 \pm 2.01^{\mathrm{a}}$ & $6.75 \pm 0.09^{\mathrm{b}}$ \\
Boiled & $12.13 \pm 0.28^{\mathrm{c}}$ & $3.35 \pm 0.42^{\mathrm{a}}$ & $2.66 \pm 0.18^{\mathrm{a}}$ & $24.30 \pm 0.31^{\mathrm{a}}$ & $57.56 \pm 0.21^{\mathrm{a}}$ & $1467.29 \pm 8.37^{\mathrm{a}}$ & $2.81 \pm 0.81^{\mathrm{a}}$ & $6.49 \pm 0.04^{\mathrm{a}}$ \\
Roasted & $4.05 \pm 0.15^{\mathrm{a}}$ & $4.40 \pm 0.51^{\mathrm{b}}$ & $3.91 \pm 0.19^{\mathrm{b}}$ & $25.69 \pm 0.33^{\mathrm{b}}$ & $61.95 \pm 0.40^{\mathrm{c}}$ & $1611.12 \pm 10.21^{\mathrm{c}}$ & $3.02 \pm 1.85^{\mathrm{a}}$ & $6.50 \pm 0.02^{\mathrm{a}}$ \\
\hline
\end{tabular}

Values are expressed as mean \pm standard deviations. Values with different superscripts in the same column are significantly different $(\mathrm{p}<0.05)$ by DMRT. 


\subsubsection{Protein content}

Raw beans contain the maximum amount of protein $(26.08 \pm 0.14 \%)$ among all samples. Roasted beans contain $25.69 \pm 0.33 \%$ protein, which is not reduced significantly than raw beans. Protein content is significantly $(\mathrm{p}<0.05)$ reduced in boiled beans

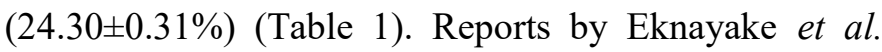
(1999) showed that the boiling process significantly reduces the protein content of beans. Water-soluble peptide molecules leach in the process of boiling. That's why protein content significantly reduced after the boiling process. Similar reports were published by Adejumo (2012), showing how protein content reduced by different types of cooking. Reports by Seena et al. (2006) indicated a significant loss of protein during boiling and pressure cooking.

\subsubsection{Carbohydrate content}

Boiled beans contain a significantly $(\mathrm{p}<0.05)$ lower amount of carbohydrate $(57.56 \pm 0.21 \%)$ than raw $(59.22 \pm 0.14 \%)$ and roasted $(61.95 \pm 0.40 \%)$ beans (Table 1). Reduction of carbohydrate content during boiling may be occurred for decreasing resistant starch content due to the destruction of amylase inhibitors during cooking, which was reported by Wang et al. (2009). Carbohydrate content was increased significantly $(\mathrm{p}<0.05)$ during roasting. It was reported by de Almeida Costa et al. (2006) that, thermal processing may increase the availability of some nutrients like starch. That's why carbohydrate content in roasted beans might be significantly $(\mathrm{p}<0.05)$ increased.

\subsubsection{Gross energy}

The energy in roasted bean was found the highest $(1611.12 \pm 10.21 \mathrm{~kJ} / 100 \mathrm{~g})$. Whereas, raw beans contain $1561.43 \pm 8.54 \mathrm{~kJ} / 100 \mathrm{~g}$ and boiled beans contain $1467.26 \pm 8.37 \mathrm{KJ} / 100 \mathrm{~g}$ (Table 1). As the boiling process reduces carbohydrate, protein and fat; thereby, gross energy was also examined low in boiled kidney bean. Similar to this study, roasted bean showed significantly $(p<0.05)$ higher energy in previous reports by Audu and Aremu (2011) for red kidney bean.

\subsubsection{Fibre content}

In the present study, the fibre content of raw bean was $5.45 \pm 2.01 \%$ which is higher than the previous studies reported for red kidney bean (3.6\%) (Audu and Aremu, 2011) and white kidney bean (4.51\%) (Olanipekun et al., 2015). It may be due to the varietal difference of kidney bean. The fibre contents in boiled and roasted beans were $2.81 \pm 0.81 \%$ and $3.02 \pm 1.85 \%$ respectively. Fibre content significantly $(\mathrm{p}<0.05)$ reduced in boiled and roasted samples but no significant differences were observed among these contents (Table 1). The reduction in fibre content in boiled and roasted sample may be due to the reason that soluble fibres become soften during cooking which reduces their content (de Almeida Costa et al., 2006).

\subsection{8 $\mathrm{pH}$ value}

The $\mathrm{pH}$ value of boiled $(6.49 \pm 0.04)$ and roasted $(6.50 \pm 0.02)$ samples decreased significantly $(p<0.05)$ than raw beans $(6.75 \pm 0.09)$ (Table 1$)$. It may be due to the compositional reconstitution which occurred during processing. Vegetables containing $\mathrm{pH}$ values near neutrality (4-6) have a significance because it enhances the shelf life by retarding the microbial growth of several pathogenic organisms which are responsible for food spoilage (Shin et al., 2015).

\subsection{Total phenolic content (TPC)}

Figure 2 represents the total phenolic content of raw and processed dark red kidney beans. Raw bean contains the highest amount of TPC $(12.55 \pm 1.42 \mathrm{mg}$ GAE/g) which is within the range of $5.87-14.14 \mathrm{mg}$ GAE/g, reported by Peters et al. (2011) for several common beans. On the other hand, TPC decreased significantly $(\mathrm{p}<0.05)$ in boiled $(5.53 \pm 0.74 \mathrm{mg} \mathrm{GAE} / \mathrm{g})$ and roasted $(8.15 \pm 1.60 \mathrm{mg} \mathrm{GAE} / \mathrm{g})$ samples.

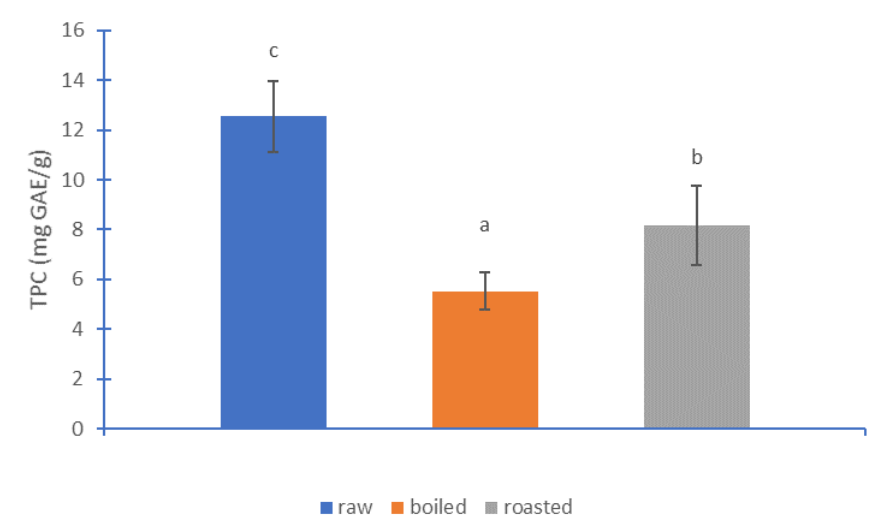

Figure 2. Total phenolic content of raw, boiled and roasted dark red kidney bean. Bars with different letters are significantly different $(\mathrm{p}<0.05)$ by DMRT

Polyphenols are thermally unstable compounds that are quickly degraded during heating (Roy et al., 2007; Podsędek et al., 2008). Decreased levels of polyphenols in boiled samples have been reported which might be due to thermally induced chemical oxidation and watersoluble polyphenol leaching, as phenols are polar compound. Maillard reactions result from high temperatures $\left(120^{\circ} \mathrm{C}\right)$ in the roasted samples which may be responsible for reducing the polyphenol levels. Polyphenolic compounds have been reported to be active in the Maillard reaction, resulting in a rise in Maillard reaction products and a decrease in polyphenol levels 
(Manzocco et al., 2000).

\subsection{Antioxidant activity}

Figure 3 shows DPPH- radical scavenging activity (DRSA) of raw, boiled, roasted sample as well as DRSA of gallic acid and commercial antioxidant ascorbic acid.

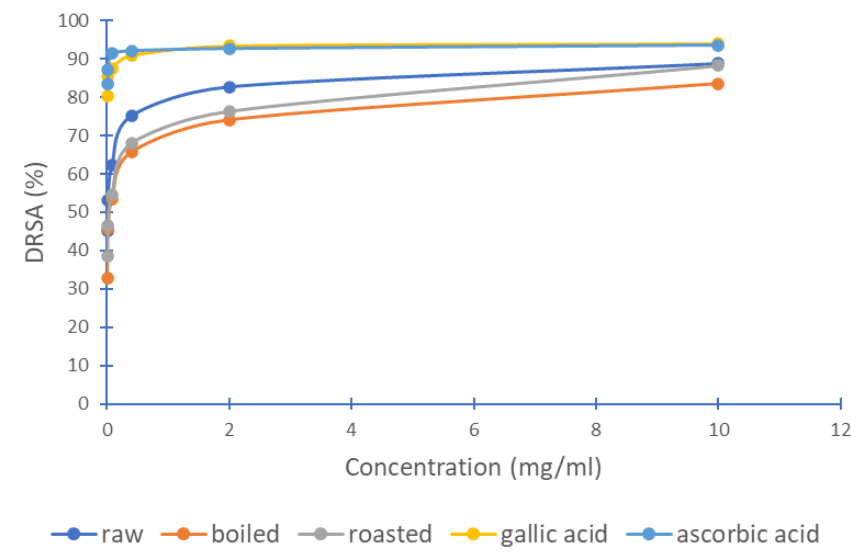

Figure 3. Antioxidant activity of raw, boiled, roasted bean, gallic acid, ascorbic acid

Raw bean exhibited the highest antioxidant activity than boiled and roasted beans with an $\mathrm{IC}_{50}$ value of $0.0144 \pm 0.0094 \mathrm{mg} / \mathrm{mL}$ (Table 2). In the present study, the raw sample exhibited $45.25 \pm 1.91 \%$ to $88.80 \pm 1.79 \%$ DRSA at a dosage of 0.0032 to $10 \mathrm{mg} / \mathrm{mL}$. A similar study was carried out by Chou et al. (2003) for $50 \%$ ethanolic red bean extract, where at a dosage of $0.62-10$ $\mathrm{mg} / \mathrm{mL}$ samples exhibited 22.2 - 80.2\% DRSA. While comparing with Gallic acid and ascorbic acid, the samples (raw, boiled and roasted) showed significantly $(\mathrm{p}<0.05)$ lower DPPH- radical scavenging activity. Significant $(\mathrm{p}<0.05)$ loss of antioxidant activity were observed during thermal processing. Polyphenol compounds are liable for showing antioxidant activity (Ismail et al., 2004). Hence, for leaching out of polyphenols, the antioxidant activity might be decreased significantly $(\mathrm{p}<0.05)$. Similar results are reported for the antioxidant activity of spices by Shan et al. (2005). A study by Othman et al. (2007); showed that roasting of cocoa beans significantly $(p<0.05)$ decrease the antioxidant activity. Cooking time is a major factor for decreasing antioxidative properties in foodstuffs like vegetables, beans, fruits etc. (Turkmen et al., 2005).

Table $2 . \mathrm{IC}_{50}$ values of raw, boiled and roasted dark red kidney bean

\begin{tabular}{cc}
\hline Type of sample & $\mathrm{IC}_{50}$ value $(\mathrm{mg} / \mathrm{mL})$ \\
\hline Raw & $0.0144 \pm 0.0094^{\mathrm{a}}$ \\
Boiled & $0.0608 \pm 0.0765^{\mathrm{b}}$ \\
Roasted & $0.0523 \pm 0.0026^{\mathrm{b}}$ \\
\hline
\end{tabular}

Values are expressed as mean \pm standard deviations. Values with different superscripts in the same column are significantly different $(\mathrm{p}<0.05)$ by DMRT.

\section{Conclusion}

This research was carried out to investigate how the physicochemical properties, polyphenol content and antioxidant activity of dark red kidney bean change through various household cooking methods like boiling and roasting. The moisture content varies from 4.13 to $12.13 \%$. Ash content was found ranging from 3.35 to $4.82 \%$. There was a high amount of protein (24.30 $26.08 \%$ ) found by analysis. The caloric value was found at $1476-1611 \mathrm{~kJ} / 100 \mathrm{~g}$, which is above satisfactory level. Considering its high protein and energy level, dark red kidney beans should be remarked as a cheap source of highly nutritious food. Total phenolic content was reduced by thermal processing ranging from $12.55-5.53$ mg GAE/g. Antioxidant activity was also reduced significantly $(\mathrm{p}<0.05)$ due to thermal processing. Raw, boiled and roasted beans showed 50\% antioxidant activity in the concentration of $0.0144,0.0608$ and $0.0523 \mathrm{mg} / \mathrm{mL}$. Therefore, it will be better to keep boiling water during household cooking. Roasting may be an effective process for long time storage as it causes minimum loss of nutrients. So, appropriate utilization of dark red kidney bean seeds will be very much beneficial for keeping the good health of the people of developing countries like Bangladesh.

\section{Conflict of interest}

The authors declare no conflict of interest.

\section{Acknowledgements}

The authors are thankful to the Food Engineering and Tea Technology Department for their material and laboratory support to conduct the research successfully.

\section{References}

AACC, C. (2000). Approved methods of the American Association of cereal chemists. USA: AACC

Adejumo, B. (2012). Effect of drying methods and pretreatment on some physicochemical quality attributes of tomato powder. International Journal of Innovative Research and Development, 1(11), 50-58.

Alam, M., Hossain, M. and Sarkar, A. (2020). Effect of Edible Coating on Functional Properties and Nutritional Compounds Retention of Air Dried Green Banana (Musa sapientum L.). IOSR Journal of Environmental Science, Toxicology and Food Technology, 14(2), 51-58. doi:10.9790/24021402025158

Audu, S. and Aremu, M. (2011). Effect of processing on the chemical composition of red kidney bean (Phaseolus vulgaris L.) flour. Pakistan Journal of 
Nutrition, 10(11), 1069-1075. https:// doi.org/10.3923/pjn.2011.1069.1075

Chou, S.T., Chao, W.W. and Chung, Y.C. (2003). Antioxidative activity and safety of $50 \%$ ethanolic red bean extract (Phaseolus radiatus L. var. Aurea). Journal of Food Science, 68(1), 21-25. https:// doi.org/10.1111/j.1365-2621.2003.tb14108.x

de Almeida Costa, G.E., da Silva Queiroz-Monici, K., Reis, S.M.P.M. and de Oliveira, A.C. (2006). Chemical composition, dietary fibre and resistant starch contents of raw and cooked pea, common bean, chickpea and lentil legumes. Food Chemistry, 94(3), 327-330. https://doi.org/10.1016/ j.foodchem.2004.11.020

Eknayake, S., Jansz, E.R. and Nair, B.M. (1999). Proximate composition, mineral and amino acid content of mature Canavalia gladiata seeds. Food Chemistry, 66(1), 115-119. https://doi.org/10.1016/ S0308-8146(99)00041-2

Folch, J., Less, M. and Sloane-Stanley, G.H. (1957). A simple method for the isolation and purification of total lipids from animal tissues. Journal of Biological Chemistry, 226(1), 497-509. https:// doi.org/10.1016/S0021-9258(18)64849-5

Horwitz, W., Chichilo, P. and Reynolds, H. (1970). Official methods of analysis of the Association of Official Analytical Chemists. USA: AOAC.

Ismail, A., Marjan, Z.M. and Foong, C.W. (2004). Total antioxidant activity and phenolic content in selected vegetables. Food Chemistry, 87(4), 581-586. https:// doi.org/10.1016/j.foodchem.2004.01.010

Manzocco, L., Calligaris, S., Mastrocola, D., Nicoli, M.C. and Lerici, C.R. (2000). Review of nonenzymatic browning and antioxidant capacity in processed foods. Trends in Food Science and Technology, 11(9-10), 340-346. https:// doi.org/10.1016/S0924-2244(01)00014-0

Nisbett, R.E. and Masuda, T. (2003). Culture and point of view. Proceedings of the National Academy of Sciences, 100(19), 11163-11170. https:// doi.org/10.1073/pnas.1934527100

Olanipekun, O., Omenna, E., Olapade, O., Suleiman, P. and Omodara, O. (2015). Effect of boiling and roasting on the nutrient composition of kidney beans seed flour. Sky Journal of Food Science, 4(2), 24-29.

Othman, A., Ismail, A., Ghani, N.A. and Adenan, I. (2007). Antioxidant capacity and phenolic content of cocoa beans. Food Chemistry, 100(4), 1523-1530. https://doi.org/10.1016/j.foodchem.2005.12.021

Peters, K., Delong, H. and Hossain, K. (2011). Anthocyanin, total polyphenols and antioxidant activity of common bean. American Journal of Food
Technology, 6(5), 885-394. https://doi.org/10.3923/ ajft.2011.385.394

Podsędek, A., Sosnowska, D., Redzynia, M. and Koziołkiewicz, M. (2008). Effect of domestic cooking on the red cabbage hydrophilic antioxidants. International Journal of Food Science and Technology, 43(10), 1770-1777. https:// doi.org/10.1111/j.1365-2621.2007.01697.x

Rahman, M.M., Bakr, M., Mia, M., Idris, K., Gowda, C., Kumar, J., Deb, U., Malek, M. and Sobhan, A. (2000). Legumes in Bangladesh. International Crops Research Institute for the Semi-Arid Tropics, 5-34.

Roy, M., Haque, S.M.N., Das, R., Sarker, M., Al Faik, M.A. and Sarkar, S. (2020). Evaluation of Physicochemical Properties and Antioxidant Activity of Wheat-Red Kidney Bean Biscuits. World Journal of Engineering and Technology, 8(4), 689-699. https://doi.org/10.4236/wjet.2020.84049

Roy, M., Sarker, A., Azad, M.A.K., Shaheb, M.R. and Hoque, M.M. (2020). Evaluation of antioxidant and antimicrobial properties of dark red kidney bean (Phaseolus vulgaris) protein hydrolysates. Journal of Food Measurement and Characterization, 14(1), 303 -313. https://doi.org/10.1007/s11694-019-00292-4

Roy, M.K., Takenaka, M., Isobe, S. and Tsushida, T. (2007). Antioxidant potential, anti-proliferative activities, and phenolic content in water-soluble fractions of some commonly consumed vegetables: Effects of thermal treatment. Food Chemistry, 103 (1), 106-114. https://doi.org/10.1016/ j.foodchem.2006.08.002

Sarkar, A., Ahmed, T., Alam, M., Rahman, S. and Pramanik, S.K. (2020). Influences of Osmotic Dehydration on Drying Behavior and Product Quality of Coconut (Cocos nucifera). Asian Food Science Journal, 15(3), 21-30. https:// doi.org/10.9734/afsj/2020/v15i330153

Sarkar, A., Arafat, Y., Alam, M. and Sarkar, J. (2020). Study on Dietary Pattern and Nutritional Status of School Going Children in Navaron, Jashore, Bangladesh. American Journal of Food Science and Technology, 8(2), 70-74.

Sarker, A., Chakraborty, S. and Roy, M. (2020). Dark red kidney bean (Phaseolus vulgaris L.) protein hydrolysates inhibit the growth of oxidizing substances in plain yogurt. Journal of Agriculture and Food Research, 2, 100062. https:// doi.org/10.1016/j.jafr.2020.100062

Seena, S., Sridhar, K., Arun, A. and Young, C.-C. (2006). Effect of roasting and pressure-cooking on nutritional and protein quality of seeds of mangrove legume Canavalia cathartica from southwest coast 
of India. Journal of Food Composition and Analysis, 19(4), 284-293. https://doi.org/10.1016/ j.jfca.2005.05.004

Shan, B., Cai, Y.Z., Sun, M. and Corke, H. (2005). Antioxidant capacity of 26 spice extracts and characterization of their phenolic constituents. Journal of Agricultural and Food Chemistry, 53(20), 7749-7759. https://doi.org/10.1021/jf051513y

Shin, L.E., Zzaman, W., Kuang, Y.T. and Bhat, R. (2015). Influence of Dehydration Techniques on Physicochemical, Antioxidant and Microbial Qualities of Ipomoea aquatica Forsk: An Underutilized Green Leafy Vegetable. Journal of food Processing and Preservation, 39(6), 11181124. https://doi.org/10.1111/jfpp. 12326

Turkmen, N., Sari, F. and Velioglu, Y.S. (2005). The effect of cooking methods on total phenolics and antioxidant activity of selected green vegetables. Food Chemistry, 93(4), 713-718. https:// doi.org/10.1016/j.foodchem.2004.12.038

Velioglu, Y., Mazza, G., Gao, L. and Oomah, B. (1998). Antioxidant activity and total phenolics in selected fruits, vegetables, and grain products. Journal of Agricultural and Food Chemistry, 46(10), 41134117. https://doi.org/10.1021/jf9801973

Wang, N., Hatcher, D., Toews, R. and Gawalko, E. (2009). Influence of cooking and dehulling on nutritional composition of several varieties of lentils (Lens culinaris). LWT-Food Science and Technology, 42(4), 842-848. https://doi.org/10.1016/ j.lwt.2008.10.007

$\mathrm{Xu}, \mathrm{B}$. and Chang, S. (2008). Total phenolic content and antioxidant properties of eclipse black beans (Phaseolus vulgaris L.) as affected by processing methods. Journal of Food Science, 73(2), H19-H27. https://doi.org/10.1111/j.1750-3841.2007.00625.x

Yen, G.-C. and Chen, H.-Y. (1995). Antioxidant activity of various tea extracts in relation to their antimutagenicity. Journal of Agricultural and Food Chemistry, 43(1), 27-32. https://doi.org/10.1021/ jf00049a007 